\title{
Majority of Bolus Remaining
}

National Cancer Institute

\section{Source}

National Cancer Institute. Majority of Bolus Remaining. NCI Thesaurus. Code C127212.

A finding of the majority of bolus remaining after swallowing. 